\title{
Kotabaru and the Housing Estate as Bulwark against the Indigenization of Colonial Java
}

\author{
Farabi Fakih
}

Introduction

With the passing of the Agrarische Wet (Agrarian Law) in 1870, which provided the legal structure for a more liberal economic development of the Netherlands Indies, the number of foreign companies and Europeans arriving in the colony steadily increased. By 1930, the European population in the Indies had grown to around 300,000 in a total population of approximately 60 million. In the cities, their ratio was much higher; in some cities, Bandung is a good example, the European population amounted to as much as twelve per cent while even in other, more native cities, as for instance Yogyakarta, it had amounted to around 4 per cent in 1930 (Volkstelling 1930 1936, VIII:2, 78-81).

The upshot of the emergence of European communities at the end of the nineteenth and the beginning of the twentieth century was the creation of small civil societies within the cities. These were composed mostly of European men, educated in Europe, who possessed technical and managerial skills. This was one reason why these colonial cities became the first sites of autonomous local administration in the Netherlands Indies. Another reason was the need for local authorities to address the crises in housing and sanitation. The centralist bureaucratic structure of colonial government clearly hampered the capacity of the cities to provide its citizens with such amenities essential to modern living as paved roads and clean water. The Decentralization Act of 1903 changed this situation radically and the first cities to acquire some form of autonomy in 1905 were Batavia, Meester Cornelis, and Buitenzorg. Legal autonomy in the understanding of the Act meant the creation of a gemeente or municipal government, with a town hall and, initially, an appointed municipal council composed mostly of European men who could make recommendations to the central government through the channels of the regional bureaucracy. This sort of advice pertained to the allocation of funds disbursed to the city. It also authorized the collection of local taxes (such as the Dog Tax) to generate local funds for its own use (Schrieke 1918:184-217).

This was also the period in which the peculiar modern fetish for hygiene and cleanliness appeared on the scene in the Netherlands Indies. The concept of bacteria and viruses and their association with disease and the environment

(C) FARABI FAKIH, 2015 | DOI 10.1163/9789004280724_007

This is an open access chapter distributed under the terms of the Creative Commons Attribution-

Noncommercial 3.0 Unported (CC-BY-NC 3.0) License. 
was becoming more generally understood. Uncovering the secrets of the deadly tropics and how white men could avoid succumbing to the diseases that lurked there became popular knowledge. In 1913, W.J. van Gorkom, a wellknown doctor in the Netherlands Indies, published a book about the requirement of hygiene in the cities of the Netherlands Indies, especially the colonial capital, Batavia. Van Gorkom urged Europeans to put the information acquired about health and hygiene into practice in their cities. He was especially concerned about health in the native quarters in the cities and the necessity of creating a municipal board of health to tackle these matters (Van Gorkom 1913:156-165).

This recommendation coincided with the movement towards greater urban autonomy; cities had to be able to take control of their own space so as to improve the hygiene of the city for the benefit of everyone. The emergence of a new type of European, often newly arrived from the Netherlands and well educated, who was punctilious about not being seen in a sarong, who lived in European-style houses, read newspapers containing articles about travel, European theatre and the latest fashion from Paris, was a significant shift from the older type of colonialist (Mrázek 2002:129-154). The older type of European in the Netherlands Indies had grown up in the land in which they had been born and who had had a much closer relationship with indigenous people. In the older cities, the spatial structure meant that, of necessity, European and indigenous urbanites generally rubbed shoulders with one another.

Modernity and its fetishes produced a new type of city design, which allowed for greater space and separation. This in turn meant that their inhabitants could distance themselves further from the land. Dirt roads were paved and the traditional linear Indies town development, which had provided opportunities for significant contact with kampong people (because kampongs were usually located behind main roads lined by European houses) (Wertheim 1956:171), was discarded in favour of one, which consisted of compact, insular housing estates producing a concentrated European environment. This development also exerted an important influence on the emergence of the housing market. There were now enough people constituting a middleclass in the Indies to represent a housing market sufficient to motivate developers to embark on the construction of housing estates. My purpose in exploring the history of one such housing estate, Kotabaru in Yogyakarta, in this chapter is to see how the development of housing estates affected the idea of the house in the Indies, how it intruded on the relationship between the Javanese and Europeans, and how, with the establishment of the government of the Republic of Indonesia in Yogyakarta, the colonial era estate continued to 
influence relations between those living in the former Europeans, housing estate and the surrounding kampongs.

\section{The Discourse of the Netherlands Indies Housing Estate}

Most of the new housing estates present in most of the cities of the Netherlands Indies (but especially in cities which had been granted municipal autonomy) were built in the course of the 1920s. The Nieuwe Wijk (Kotabaru) housing estate in the city of Yogyakarta was begun in 1919. Other examples were Menteng and Gondangdia in Batavia, Nieuw Tjandi in Semarang, Gempol in Bandung, Djati Oeloe in Medan, but there were many more (Flieringa 1930). These new housing estates formed part of the changing shape of cities in the Netherlands Indies. Designed using contemporary town planning technology and incorporating many of the contemporary modern amenities of European cities, including mains delivering potable water, paved roads and footpaths, they were usually rounded off with the provision of a wide range of sporting and educational facilities.

These new housing estates grew at a time when the idea of the garden city, promoted by such people as Ebenezer Howard in England and Frederick Law Olmsted in the United States was gaining ground (Tafuri and Dal Co 1986:22-33). The architect Thomas Karsten, one of the main town planners in the Indies, designed housing estates which took account of the contours of the land and constructed curvilinear streets to accentuate the atmosphere of the European countryside, but still working within a strict plan of regulated space that provided for the needs of what he saw as the differing socio-economic categories of a modern society that he believed the Netherlands Indies would become (Coté 2004:19). The idea of using nature, particularly trees in urban landscapes, to conjure up an image of nostalgic romanticism for the then fading old rural life of Europe but now integrated with modern technology, was gaining ground. The houses themselves were now being designed according to the new ideas about what constituted modernity; in Bandung especially, houses were being designed with a decidedly modern Art Deco style. The old Indies-style houses, with their main galleries and front and back verandas, their outhouses and spacious living arrangements were being replaced by compact, two-storey houses, very European in style and design, with a modern bathroom and even some air conditioning.

Modernity arrived in the Indies city in full force via various new discourses such as those associated with the idea of hygiene and health, but it also came as part of the burgeoning sense of European-ness in white colonial society in the Indies (Locher-Scholten 1997). This new awareness was probably 
accelerated by advances in modern communications technology and modes of travel. The pervasiveness of Hollywood in colonial Dutch-language newspapers indicates the development of a sense of closeness with the West and consequently such images transmitted by the media demolished the sense of insularity of Indies life. But this sense of connectedness to the West also produced a different sense of insularity within the Indies. The new housing estates can be considered to have represented islands of modernity; places in which the presence of the non-modern, that of the Javanese and their kampongs, was relegated to a well-concealed background. By looking at one housing estate, the Kotabaru housing estate in Yogyakarta, it is possible to see that its design went beyond the intention to establish a romantic sense of old rural life; it was a deliberate attempt to disconnect it physically from the rest of the 'native' city.

I shall come back to this later, but at this juncture I am interested in looking at the ideas some Europeans fostered about their living space. It was difficult to find former European inhabitants to interview and I was therefore compelled to try to find other sources. A good fount of information is housing advertisements. In what follows I shall examine a series of housing advertisements in an effort to analyse the spatial discourse about housing current in late colonial Indonesia.

As the purpose of advertisements is to sell dreams, they tend to be quite explicit in their message. Housing advertisements, therefore, can provide a rich source for understanding a wide range of the elements, which composed the European perspective in the colony. Only a preliminary glance can be attempted here and this should be the subject of a much deeper research. They represent an interpretation of part of a much more extensive European discourse which first and foremost encompassed the idea of the house and then went a step further to include the idea of who the house-seekers were and where they wanted to go. Unfortunately the use of housing advertisements seems to have stopped after Independence. I have not yet been able to find any advertisements for privately constructed housing estates placed in the newspapers in the 1950s and 1960s. Only after the end of the 196os, during the New Order era was there a return to housing estates and with this, of the reappearance of their advertisements in newspapers and magazines.

The series of advertisements I want to use for this purpose is related to the Villa-Park Tretes in Tretes, not far from the city of Surabaya. Unlike the majority of housing estates developed by local governments, this one was developed by a private company named Woning-en Administratie Bureau van Vloten. Created by the Surabaya-based real-estate developer C.F. van Vloten Augustijn, Tretes was widely advertised in the newspapers and in Van Vloten's own fortnightly catalogue of vacant houses. Located at around 900 metres above sea 
level on the lower slopes of Mount Arjuno, in the environs of the city and connected to it by a good road and a bus service, the villa estate contained around 100 villas for sale or for rent (FWD 1935a, 1935b). The principal target group of this housing estate was Dutch families living in Surabaya, who wanted a chance to live in the cooler climate of Tretes. The housing estate offered electricity, water mains, a swimming pool, restaurant, schools and a sporting field, which appear to have been the kinds of amenities expected to be on offer in these types of housing estates. It also offered a daily bus service to Surabaya.

One such advertisement for Villa-Park Tretes was published in the Dutchlanguage newspaper De Indische Post on 26 March 1936. It pictures a boy smiling at the camera wearing a type of traditional clothing worn by a German boy, suggesting a rural idyll. He is placed alongside a letter that he has written to his readers. Written in rhyme, the letter runs as follows:

Tretes, 26 March 1936

Dear Girls and Boys!

I am a nephew of BUNGALOW BILL,

I can ride and swim, as much as I like

And climb mountains, and wander through valleys

And I can go to the SPORTPARK without having to pay

In VILLA-PARK TRETES, at the edge of the forest

BUNGALOW BILL has built a LOG CABIN for me,

I have a [illegible] there, dressed in hiking clothes

And I go to the VILLA-PARK SCHOOL, Oh what a joy it is to learn!

It is an unforgettable spot here,

You learn all sorts of things here people need to know

And when I am grown up, I shall hang out the signs

And I want to become a builder of bungalows myself!

Of course, I shall also open a school myself

And for the children of the future, learning will become the watchword

But what I actually would like to ask you here

Is: shall I see you all show up in TRETES for EASTER?

Well, that's all done and dusted! Goodbye

From me and of course from BUNGALOW BILL

A firm paw

From your Billy Ketjil ${ }^{1}$

1 The original poem reads: 'Trètès 26 Maart 1936 Beste meisjes en jongens! Ik ben een neef van/ BUNGALOW BILL, Ik mag rijden en zwemmen Zooveel als ik wil, Ik klauter op bergen En zwerf 
Billy Ketjil is a very happy boy, because he lives on the Villa-Park Tretes housing estate. The Villa Park offers amenities where he can play all day and attend a good school. And this is not all; he can play wearing his hiking gear (bergklimmerskleeren) and can smile at the camera in the guise of a boy from the German Alps.

The idea of escaping to the cool, healthy mountains away from the debilitating tropics and the concomitant fear of the effect of the heat and disease had a very long history in European discourse on Indies. Almost every major city in the Indies had a local mountain retreat where Europeans holidayed and recuperated. In the 1920s such places were transformed into destinations to which 'ordinary' Europeans flocked at the weekend. Modernity now offered the mountain as a place where families could relax all day long. They could rent or even own a house in such a resort and yet remain in easy reach of the city via a daily bus service which would transport the working father to the hot, tropical city below while his wife and children continued to enjoy the clean, fresh, healthy mountain air.

Almost all the advertisements show a sketch of what was on offer as a potential client's future home. None bears any resemblance to the traditional European Indies house; instead they were modelled on and reminiscent of traditional European houses, even traditional European mountain chalets. One advertisement ran:

One misses one's own fireplace as strongly in the tropics as one misses the sun and blue sky for a significant part of the year in Holland. But...in Tretes one has to forfeit neither one nor the other. So buy or rent one of these Cosy Bungalows there. They are only to be found in Villa-Park Tretes.

door de dalen En ik mag in het SPORTPARK Zonder betalen. In het VILLA-PARK TRÈTÈS Aan de zoom van het woud, Heeft BUNGALOW BILL Mij een BLOKHUT gebouwd, Ik heb daar een [illegible] In mijn bergklimmerskleeren En ga naar de VILLA-PARK SCHOOL Om fijn wat te leeren! Het is daar een tempat Om nooit te vergeten Je leert er van alles Wat een mensch dient te weten En ben ik straks groot Dan verhang ik de borden En wil zelf een bouwer van BUNGALOWS worden! Dan open ik natuurlijk Ook zelf een school En voor toekomstige kinderen Wordt dan het leeren parool, Maar wat ikjullie eigenlijk Bij deze wilde vragen: Ik zie jullie met PASCHEN; Toch allemaal op "TRÈTÈS" opdagen? Nou, dat is in orde en verder gegroet, Van mij en natuurlijkvan BUNGALOW BILL En een ferme poot van je BILLY KETJIL'. Interestingly, Billy's other name, Ketjil (Indonesian for 'little') and hence Little Billy, is a reference away from a strictly European to an 'Indies' styling, as is the term tempat (Indonesian for place). For the translation I have received kind help from Tessa de Ryk van de Gracht. 
Another declared:

High in the Cool Mountains, your family will discover health and happiness. Build or rent your own Bungalow in the mountain village closest to Surabaya [of all mountain resorts], in the Villa-Park Tretes.

Yet another advertisement stated:

Forest and sun and the high mountain air will ensure your family's health and happiness. Buy or rent for temporary or permanent residence one of these enormously cosy bungalows in the Villa-Park Tretes. $^{2}$

The texts were accompanied by drawings of an open fireplace, a chalet with pine trees, and a Dutch-looking villa.

The idea that air and coolness were important to health was a major element in the discourse of the housing estate. This was the time when climate was believed to have an influence on any number of matters. People even believed that living in cooler climates encouraged intelligence. In a sense it was another version of today's air-conditioned lives of the Indonesian middle class who, equally apprehensive about battling tropical heat, cocoon themselves in the modern amenity of technological cooling.

\section{Modernization and the Fear of the Kampongs}

What was not explicitly expressed in these advertisements was a fear of the Javanese. In fact, the Javanese did not exist for the Europeans. If one did not know the geographical location of Surabaya or Tretes, one might have thought the estate was in Europe. Only in one of the advertisements referred to above

2 The original texts (all from issues of De Indische Post in 1936) are: 'DE EIGEN HAARD mist men in de tropen even sterk als men in Holland gedurende een groot deel van het jaar de Zon en de Blauwe Hemel ontbeert. Maar...OP TRÈTÈS mist $u$ het een, noch het ander. Koopt of huurt dus een der knusse bungalows, zooals alleen VanVloten die bouwt in HET VILLA-PARK "TRÈTÈS"; 'HOOG in de KOELE BERGEN vindt uw gezin gezondheid en geluk - Bouwt of huurt Uw eigen Bungalow in het dichtst bij Soerabaia gelegen bergdorp, in het VILLA-PARK "TRÈTÈS"; 'BOSCH EN ZON en HOOGE BERGLUCHT schenken uw gezin gezondheid en geluk. Koopt of huurt voor tijdelijke of permanente bewoning een van die intens gezellige Bungalows in het VILLA-PARK "TRÈTÈS". 
was there a fleeting recognition of the tropics. Sketches of American-looking houses and German-looking bungalows or a European fireplace hint at what the Europeans were thinking when they read these advertisements. They were published in the company of articles on film stars such as Greta Garbo and Jean Harlow or advertisements for ship sailings or what was on at the Capitol Theatre in downtown Surabaya (such as Call of the Wild with Clark Gable, Loretta Young, and Jack Oakie).

European colonial society was composed of Europeans, whether trekkers or blijvers. The trekkers were those Europeans who had migrated to the Indies with plans to return to Europe; the blijvers had grown up in the Indies and planned to remain there (Van Doorn 1994:23-24). Many of the latter were of mixed parentage with familial links in Javanese society and had lived in the colony for generations (Bosma and Raben 2008). Although somewhat simplistic, these were expressive terms and, confronted with newspapers filled with references to the outside European world, whether in the USA, Australia, or Europe itself, one is forced to draw the obvious conclusion that increasingly, the European community in the Indies was dominated by the trekkers.

Modernity in the form of segregating people on the basis of a 'racial' category and modernization in the Indies, as Locher-Scholten (1998) has shown us, was providing many forms of refined racism. Although not necessarily excluding rich Javanese or Chinese, the entirely Dutch-focused advertisements for Villa-Park Trètès were clearly responding to European ways of thinking. Therefore it is safe to suppose that these advertisements were published only in Dutch-language newspapers. Even the image and appeal of the little boy was chosen to expand this sense of exclusiveness, underlying the assumption that this housing estate was intended for Europeans.

Modernity, represented here at many levels, was not liberating people from the segregation of the past; quite the opposite in fact: it was evidently developing new ways and forms of segregation defined by the logics of the market and technology. Fear is not highly apparent in these advertisements. As we have seen, instead the Javanese is conspicuous by his absence, as is the indigenous kampong of the old city. However, it is precisely the social and environmental exclusiveness suggested by the advertisements that reveals the new fear of the kampong. It is a fear, which had been submerged by the manifestations of modernity.

\section{Kotabaru and Its Relationship with the Surrounding Kampongs}

The bulk of my research was conducted on Kotabaru, where I have had the opportunity to interview fifteen people who had lived there or in one of the 
neighbouring kampongs at one time or another. ${ }^{3}$ The interviews aimed to probe in detail the nature of the relationship between the kampong and the housing estate. The interviews themselves were difficult, because I needed to obtain information about what my interviewees had felt and understood in the past, typically when they were children. This knowledge of the past is now cluttered with, and obscured by, knowledge of the present and, in some cases, this hampered the respondents' ability to make definitive statements. I shall try to explain what I have obtained from the interviews I conducted, but before I do so, I need to explain the history of Kotabaru itself.

The Nieuwe Wijk, or Kotabaru, was built around 1919 and at the time was located right at the edge of the city (Dingemans 1926:109-112). The city of Yogyakarta is a relatively new city, founded in 1756 as a result of the splitting of the Mataram kingdom into the two principalities of Surakarta and Yogyakarta in 1740 (Noorduyn 1986:89). The city was unique in that it was still the seat of a sultanate and was endowed with privileges, which few other cities in the Netherlands Indies enjoyed. Every new Sultan had to negotiate his power with the Dutch upon his succession to the throne (Houben 1994:75). With each succession, the Sultan inexorably felt his grip over his city weakening. The situation was certainly changing for Yogyakarta in the second half of the nineteenth century. The train service arrived here in the $1870 \mathrm{os}$, its lines slicing the city in two. Yogyakarta was increasingly industrialized to accommodate the expanding sugar industry. Much of the outskirts of Yogyakarta was transformed into sugarcane plantations, equipped with their own sugar factories. The consequence of this expanding industrialization was that more and more Europeans arrived in the city. The yellow pages of a telephone directory issued in 1938 reveal that Yogyakarta offered a number of amenities which the European populace could enjoy; including some jewellery shops, a piano shop and several motor car dealers (Interlocale telefoongids 1938:247-26o). The Europeans also had the European Club (sociëteit) at their disposal. This had a room for gentlemen and organized plays and dances.

Under the prevailing national agrarian law, Dutch as well as other foreigners were not allowed to own land, but on the orders of Resident Canne and the Sultan, a commission on land was formed (Commissie voor het Grondbedrijf) resulting in the Sultan's Law 1917/12, which permitted the sale of the Sultan's land to foreigners. In fact, in 1925 the former intricate Patoeh system of landownership was completely dismantled. Yogyakarta was becoming a modern

3 Respondents: Ms AD, age 77; Mr DS, age around 70; Ms E, age 55; Ms I, age around 50; Ms L, age 72 ; Mr N, age 56 ; Mr PM, age 78; Mr P, age 40; Ms R, age 66; Mr S, age 84; Ms SUK, age 75; $\mathrm{Mr} \mathrm{S}$, age 39; Ms SZ, age 76; Ms S, age 71; Mr TS, age 59. 
city and it was shedding many of its feudal laws. Two years later, work on the Nieuw Wijk was begun. It was designed by Thomas Karsten and its purpose was to provide for the housing requirements of Europeans, allowing them to obtain land and a house. It was also designed to avoid land speculation, which was becoming a problem in some cities in Java at the time. Like Tretes, Kotabaru was in a way an insular piece of ground. It had the best schooling facilities in the city; it also boasted a sports park, including a swimming pool.

A bird's eye view of Kotabaru reveals that, at the time it was built, it was bounded on the west by the Code River, on the south by the train lines, and on the north and east by farmlands. Its curving streets betray the garden-city concept- the introduction of a village atmosphere into the housing estate. Within its borders it contained a public hospital (the Petronella Hospital, today the Bethesda Hospital) and a military hospital. Barracks for the soldiers stood in the vicinity of the military hospital. It also had a complete set of schools: Kweekschool voor Inlandsche Christelijke Onderwijzers (Training College for Indigenous Christian Teachers); a Normaalschool voor Inlandsche Onderwijzeressen (Training College for Indigenous Female Teachers); the Keucheniusschool (a Christian high school); an Ams (High School for Girls), a Christelijke mulo (Meer Uitgebreid Lager Onderwijs, Christian Advanced Elementary School); and a State Europeesche Lagere School (European Elementary School). Furthermore, a seminary and Protestant church were also established in Kotabaru. There was even a museum of antiquities. In the centre, there were tennis courts and a football field.

At first glance, it can be seen that the designer maximized a sense of being somewhere else than in Indonesia. The riverside of the housing estate, a respondent informed me, was once lined with trees, obscuring the other side of the river from view. The train lines were an effective means to disconnect the area from the rest of the city to the south. Kotabaru itself was designed with newer types of houses. Although not the types of highly modernized houses which could be found in Menteng (Batavia), or the Art Deco styles in Bandung, there was a definite difference from the previous, more hybrid Indies-European houses which then existed in other parts of the city. Technically it was possible to live in Kotabaru without having to venture outside it.

Apart from the Kotabaru housing estate itself, there were several small kampongs, which encircled the area, including the kampongs west of the river and south of the train lines. Before Independence there were two kampongs located to the west of the Code River, kampong Gondolayu, located just north of what is now known as Jendral Sudirman Street, and to the south of what is now the Kampong Code, and kampong Terban. On the southern side of 
Kotabaru (but north of the railway lines), where present day kampong Krasak is located, was once a cemetery and there were also some housing estates and a kampong south of the train lines, including kampong Pengok and the European housing estate, Batjiro These various kampongs held a special position within the spatial hierarchy of the area. As will be seen, although the Kotabaru housing estate was built to provide for a sense of being somewhere else, it was the kampong that provided for the essential services, which sustained it.

The kampong inhabitants that provided the essential services required by those living in the housing estates included housekeepers, gardeners, chauffeurs, and even delivery boys who ran the messages. I have interviewed a number of persons who had lived in the kampongs surrounding Kotabaru during the 1920s. When asked what their strongest memory was, one male respondent, Mr S, replied that his strongest childhood memory of Kotabaru was a feeling of fear. He never had the courage to venture into the housing estate. When I asked why, his answer was:

because my parents forbade me to go there. Kotabaru was a Dutch place was it not? First, I was afraid of the Dutch. Secondly I was afraid of their dogs...Well, you know everyone was afraid of dogs.

Another informant, Mrs SZ, lived in kampong Klitren Lor, east of the housing estate, and adjacent to the military barracks. When asked if she had ever gone into a Dutch house, she answered: 'Never, I was afraid. Those who did go into their houses were either their maids or their mistresses'. She elaborated:

I was afraid [of venturing into Kotabaru], I was fine if I was at the border. That was because I was a girl. It was scary to go into Kotabaru, because the sinyos were often naughty. I heard that many kampong kids had fights with the sinyos. That's why people here were afraid of entering Kotabaru. ${ }^{4}$

Other respondents I talked to recalled that people were afraid to venture into Kotabaru because the white children there liked to harass the Javanese. Peasants going to their fields would rather go right around it than traverse its borders.

I received quite a different response, however, from MrPM, born in Kampong Terban in 1928, whose mother was cook in one of the girls' schools and whose

4 'Sinyo' possibly used here generically to refer to Dutch children, or more precisely refers to Europeans of mixed descent. 
father worked as an attendant at a petrol station in Kotabaru. For him, playing in Kotabaru was not scary at all 'because, to be honest, the Dutch kids there were not as nasty as the ones near the Fort' (interview with Mr PM). He and his friends often went there to steal fruit.

The responses generated by Kotabaru amongst residents of the surrounding kampong, therefore, could be quite diverse, ranging from a sense of fear to a confidence that this estate presented new opportunities. The childhood memories of my respondents in turn seemed to depend on the extent to which adult kampong residents had established a linkage with the neighbouring European estate. Thus, it is notable that $\mathrm{Mr} \mathrm{S}$, who recalled only a sense of fear with regard to the European estate, also believed that no one from his kampong, Gondolayu, worked in Kotabaru, whereas Mr PM, who recalled confidently entering the district averred that many people from Terban worked in Kotabaru before Independence. He recalled people, presumably neighbours, working as maids, gardeners, launderers, or drivers for the Dutch. These connections resulted in an asymmetrical relationship between the kampongs and Kotabaru. Where, as in the case of Kampong Terban, that connection was often at the level of providing domestic or other service, it generated an ambiguous relationship, which, as Locher-Scholten has suggested, was both close and distant (Locher-Scholten 1998). If Mr PM's childhood memory is typical, familiarity with Kotabaru - presumably provided via his parents' reports of European privilege and behaviour gathered as a result of their close but subservient relationship - generated in the child a confidence, which extended to a readiness to steal. On the other hand, again, according to Mr PM, Europeans almost never crossed the boundary of the housing estate into the kampong, the only occasion he could recall was when his mother's employer visited their house when his mother was ill.

Another level of relationship with Kotabaru operating amongst nearby kampong dwellers, was the relationship with the Roman Catholic church located within the European estate for those who had converted - or who may have been considered potential converts - to Catholicism. They were visited quite regularly by Roman Catholic priests and their Javanese church assistants from the seminary in Kotabaru, Mr PM recalled. Mr PM's family was part of this community which is likely to have played a part in his parents obtaining responsible positions in Kotabaru. This level of familiarity no doubt also contributed to Mr PM's confidence in associating with the white and Eurasian children of the estate compared to the childhood recollections of the other respondents cited above.

The relationship between the indigenous people and the Dutch was always ambiguous. There can be no denying that there was a sense of mutual fear. 
Despite this, they were inextricably linked within a colonial relationship. Even the European woman who had to venture into the kampong had some sort of relationship with the Indonesian woman she was visiting. The ambiguity is depicted in Breton de Nijs' novel Vergeelde portretten (Faded Portraits) in describing the matriarch of the house, Ms De Pauly or Aunt Sophie, and her maid, Midin. Aunt Sophie was a formidable lady, who feared that her family was becoming 'Javanized' and insisted that her family behaved in very European ways, in their manners and tastes while simultaneously believing in many of the traditional Javanese beliefs about good luck and ghosts. Midin was one of the family's maids who had an uneasy relationship with Aunt Sophie. Every time Midin disagreed with Aunt Sophie, she would escape to the kampong until her money ran out when she would return. Although each seemed to dislike the other, they were both bound together in a strange colonial relationship (Breton de Nijs 1999). The relationship was thorny but nevertheless emotional and quite real and it was a relationship that was changing as a result of modernization itself. As Elsbeth Locher-Scholten has shown, because of books such as Catenius van der Meijden's Ons Huis in Indië, modernity made people less easily 'touchable'. The overriding concern of modernity with hygiene and cleanliness translated into cleanliness from the 'pollution' of 'verindischen' (becoming indigenized). This was also what Aunt Sophie was most worried about.

The housing estate formed part of an onrush of modernization and the concomitant formalization of relationships. Housing estates formed a way of protecting Dutch people from the process of 'verindischen'. Kotabaru formed a secluded zone, designed to be separate from the city. This fear of indigenization was not immediately evident in the advertisements discussed above, but it lurked behind the advertisements. Fear formed the backdrop to the desire to build secluded housing estates. The same fear might explain the obsession some Dutch-language newspapers, such as the De Indische Post, had with travel, Hollywood films, and Paris fashion. These items in De Indische Post lift the tip of the veil of the desire of European colonials to escape from the Indies. Similarly, advertisements for housing estates show houses, which were not in the Indies at all; they showed chalets straight from the Alps, houses reminiscent of Europe. This 'running-away-from' tendency was perhaps a form of selfprotection: the housing estate can be seen as an evasion; modernization as an attempt to escape from the colonial encounter. Encountering was a form of pollution and housing estates provided the seclusion which precluded such a danger: they enabled people to live in one city but not have to meet its colonial reality. The irony was that to preserve this illusion of separation, it was necessary to have Javanese to fetch daily necessities for the modern, European neighbourhood. 


\section{The Postcolonial Discourse of the Housing Estate}

The Kotabaru housing estate was taken over by Japanese authorities during the Second World War. With its Dutch occupants gone, they began to offer the houses to Javanese on lease. Some of the houses were also commandeered by the Japanese military forces. Practically all the indigenous people who came to live on the housing estate were middle to upper class. A number of them were schoolteachers, which at the time was a very respectable, well paid occupation. But the new occupants who came to settle there during the Japanese occupation and the subsequent Revolution also included many upper class Javanese, regents, and aristocrats from other parts of Java who sought to reside in the formerly European-owned houses.

Although a small battle was fought in Kotabaru during the Japanese occupation, few buildings were destroyed so that after the war practically all the houses were still intact. Although there were few physical changes, there was a definite social change in the housing estate. There were no more Europeans walking their dogs in the morning or the afternoon. And, although many people were traumatized by the events of the war, especially because Kotabaru had been the main place of residence of the Japanese army of occupation, there was an unequivocal sense among kampong dwellers according to those I was able to interview that the spatial meaning had changed.

Almost all the respondents who had lived in Kotabaru after Independence came from a middle or upper class family and had enjoyed a good education. Three of the respondents were academics from the local Universitas Gadjah Mada. Their parents had been fluent Dutch speakers and all had enjoyed a good education, some even in the Netherlands. They had been subject to a fairly strict upbringing that instilled in them a blend of Dutch and Javanese manners. Since upper class Yogyakarta people already had a house or dalem (residence of a high official) in the city and had not needed to move to Kotabaru, almost all of the new residents of the estate had been born outside the city of Yogyakarta.

When Yogyakarta was declared the capital of the Republic of Indonesia in 1945 , it became a highly desirable location, particularly given the instability elsewhere in Java. Many people holding high positions in the new government, as well as regents from other regencies in Java, professionals including doctors and lecturers, teachers as well as some high-ranking army personnel, came to live in the city. Many of them were highly Westernized, holding parties and wearing Western-style dress as they were photographed posed in front of their cars. Even before Independence, they had already been enjoying a life-style, which was beyond the ken of ordinary people in the archipelago (Figures 6.1 
and 6.2). Their manners, the way they brushed their teeth everyday or dropped into a bookshop indicated that they were a prototype for the present-day, middle class Indonesian.

For many who formed this Indonesian middle class, living on a housing estate was something very new. The Javanese lower classes lived in kampongs, but the Javanese middle to upper classes had also lived in kampongs in colonial times. ${ }^{5}$ The Javanese nobility of Yogyakarta lived in dalem, which were

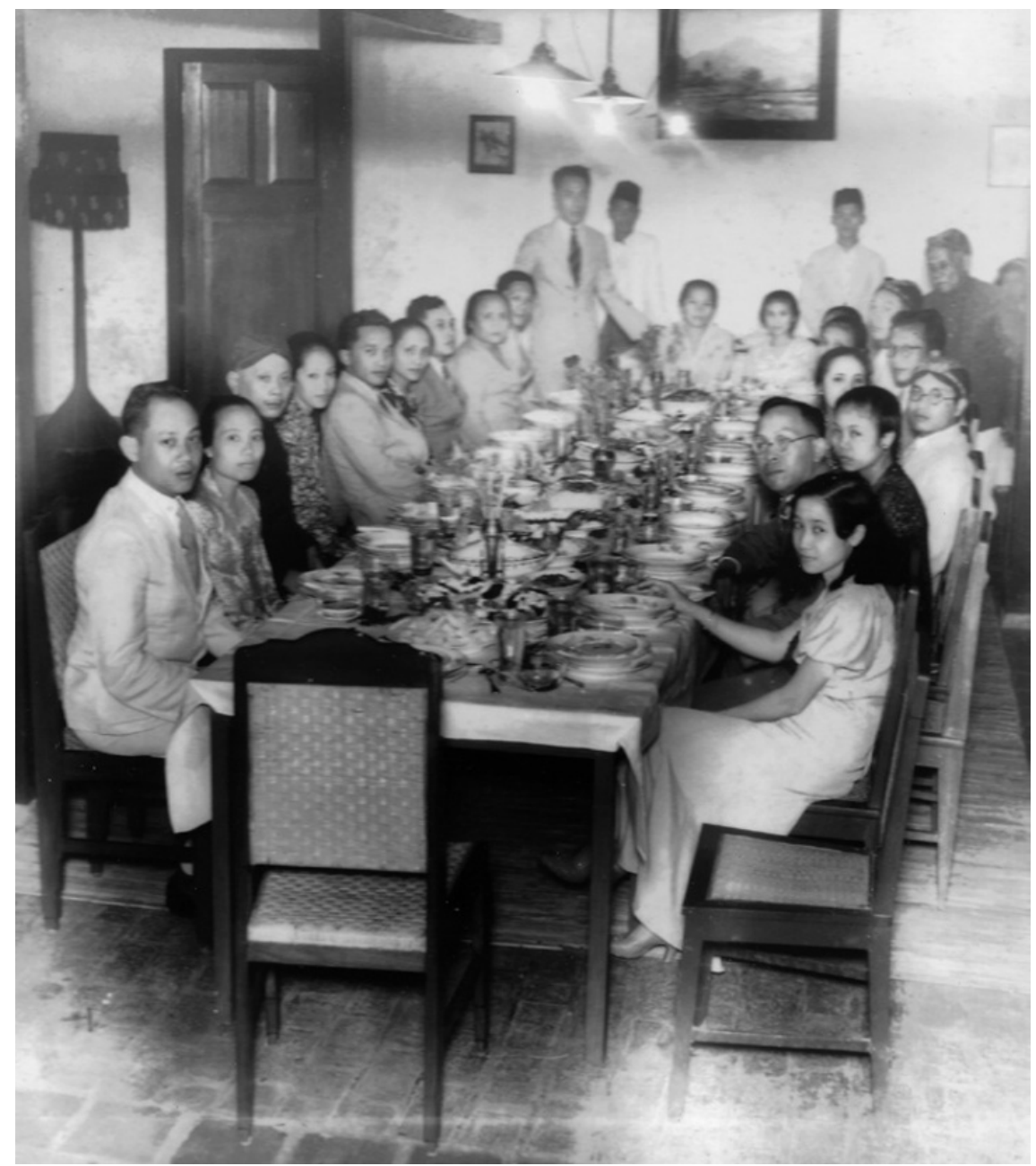

FIGURE 6.1 A party in an Indonesian-owned house, circa 1930 COURTESY OF FORT VREDENBURG, YOGYAKARTA

5 See, however, Colombijn (2010) for an alternative view on this matter. 


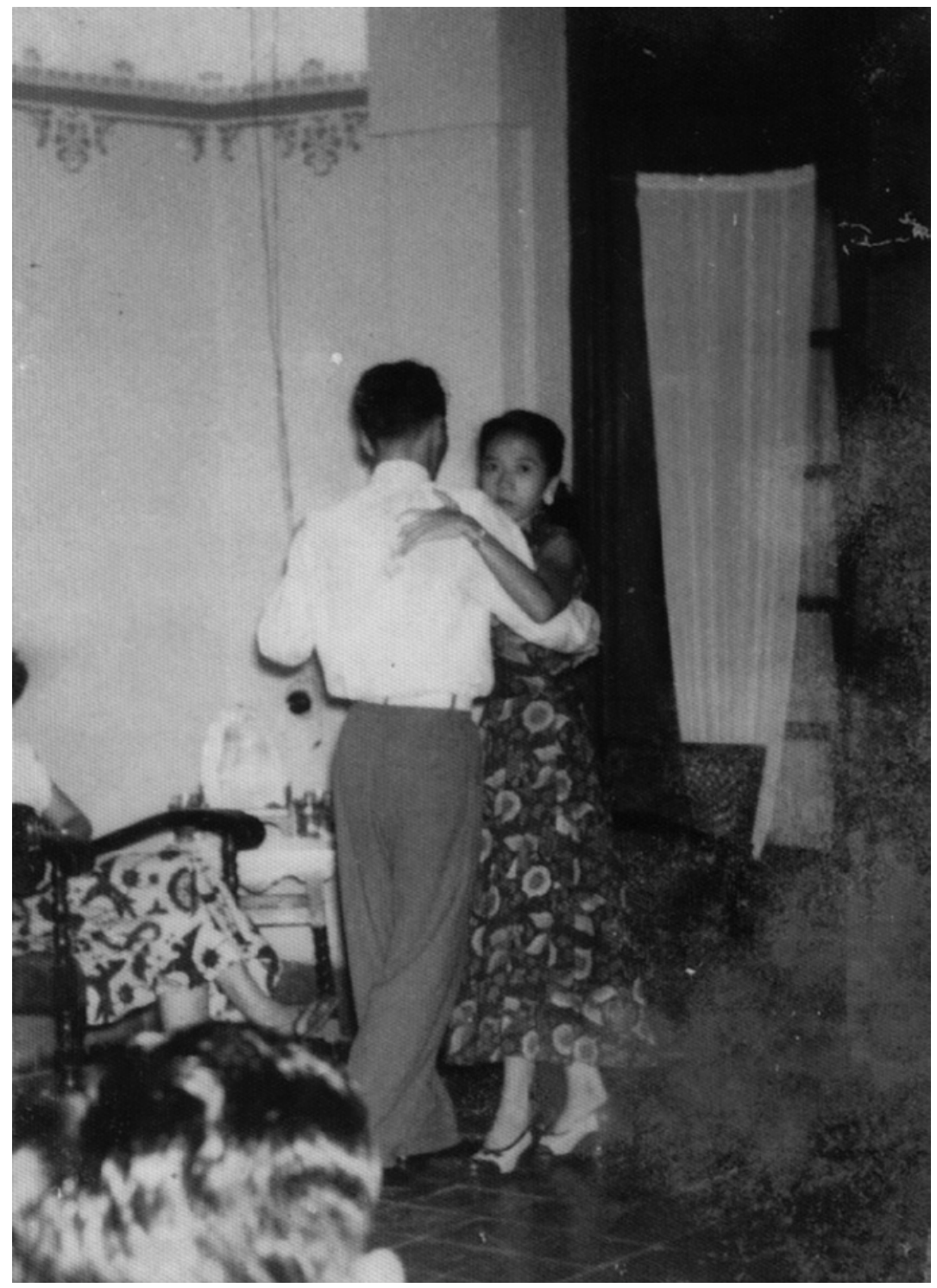

FIGURE 6.2 A dance party at a house in Kotabaru in the 1950 s COURTESY OF MS ESMERALDA SOSRONEGORO

essentially kampongs with a big house in the middle (O'Connor 1983:10). Around the houses of the nobility clustered the dwellings of abdidalem, people who functioned as their servants. The abdidalem provided the owners with various services; some mundane, others imbued with more complex social and cultural meanings. Interestingly, after Independence, the houses of Kotabaru 
gradually began to assume some features of a dalem. Their new occupants brought their dependants along with them, as seemingly people from noble families especially could not do without followers. As a result of this influx, the house and yard surrounding these houses became increasingly cramped. Outhouses and many of the internal rooms were used to house the dependants.

By turning each house into a kind of small version of a dalem, by allowing followers to live with them in the relatively large houses, the newcomers fractured Kotabaru into small territorial units. Simultaneously, they changed the dynamic relationship between the surrounding kampongs and Kotabaru itself. The organic sense of relationship which had existed during colonial times between the kampongs (especially Terban) and Kotabaru was gone. The mother of $\mathrm{Mr} \mathrm{S}$, for instance, had complained to him that 'beginning with the Japanese era, jobs had become scarce. People had to find ways to make a living'. This was why Mr PM said:

Some had commenced selling fried snacks, some sold fried peanuts, and in the morning some people had begun to sell pecel [salad with peanut sauce]. My mother, who had grown used to cooking for the boarders in the girls' school, took up selling pecel then. She used to sell on that slight elevation over there, the one being built on, in the morning. There was a yard there back then.

As the traditional Javanese way of life remained strong, people from the kampong began to undertake the essential traditional rituals which were common in villages in Java, but which could not be performed by the residents of Kotabaru. When a person died on the housing estate, for instance, someone had to initiate the one week of prayer and the other rituals related to a death. When a person was to be married or circumcised, quite a number of people were required to execute these complex rituals. To ensure the success of these traditional Javanese rituals, people had to gather, pray and chant. It would have been impossible for the new people from the housing estate to do this. The housing-estate dwellers were mostly professionals, who were unlikely to have had the time to spend on performing what they may have regarded as the tedious essentials required by the traditional ceremonies and indeed may have lost the knowledge of how they were to be performed. The kampong dwellers had to do this for them.

At the same time, apart from the ritual occasions, contacts between Kotabaru and the kampongs declined; within the residential area people also became less close. The spatial arrangement of the houses had made the 
neighbourhood as a whole less organic. Each family became an island unto itself. People met friends and other people at work and not in their neighbourhood. Although this situation has become the common state of affairs today, it must have been revolutionary at that time. The change must have produced a certain type of new Indonesian. The big houses and their big spaces were totally different to the narrow footpaths and snug lanes of the kampongs; where intimacy was prevalent, and the border between one house and another was never clear. When asked about how close she was to her neighbours, a respondent who had lived in Kotabaru all her life answered:

Yes, we were close, but not as in the kampongs. That's because houses in Kotabaru were large. It wasn't as it was in the kampongs, where you'd meet your neighbours after waking up. It was different there, there was more privacy. So the relationship patterns were a bit different (interview with Ms E).

\section{Conclusion}

The development of housing estates can be seen as part of the greater process of modernization in the Netherlands Indies. The rise of housing estates was also a part of the greater spatial changes taking place in the Indonesian cities. The former spatial formation of the Indies cities, which had placed Dutch houses side by side with native kampongs, had generated regular interaction between the Dutch and the Javanese. Modernization resulted in an everwidening distance between and among the ethnic categories. The housing estate presented a closed space; a new form of urban site outside which the Europeans (at least the women and children) did not have to venture. Or perhaps they only crossed the boundary when they wanted to attend a ball at the sociëteit or urgently needed to buy something in one of the European or Chinese shops. In a way, the situation resembled that in today's gated communities. This fear of the outside was not a fear of crime, but the fear of indigenization. The latent fear of Europeans of indigenous people was to some extent reversed where some indigenous people living in the surrounding kampongs feared Kotabaru. Others, however, went there daily to work for the middle and upper class residents of the housing estate, and did so again after Independence.

During the Japanese occupation, the Europeans living in Kotabaru had either been interned or had fled the city and their vacant houses were occupied by Indonesian professionals. The change in life-style was less radical than the shift from European to Indonesian residents might have suggested. 
The new occupants were people who had already become acculturated to a Western way of life. Nevertheless, they introduced a new style of habitation. They considered their house to be in many ways similar to a dalem. Many began to open up their houses to relatives or other followers in the traditional spatial way of giving land or space to dependants, thereby binding them in a new semi-feudal relationship. As a corollary of the new social structure taking shape on the housing estate, their relationship with the kampongs surrounding Kotabaru was obliterated. The daily work relationship between servants and the lady of the house of colonial times was replaced by a more traditional relationship; one which involved the employment of kampong dwellers in the traditional ceremonies which members of the Indonesian middle class in Kotabaru were unable to perform, but to which they had been accustomed in their childhood.

The change in social relationships prompted other changes as well. During the 1950s, some areas of Kotabaru degenerated into seediness. The area near the Code River became a place where prostitutes gathered. Inhabitants of Kotabaru were reluctant to sit in their front gardens for fear of falling victim to a crime. The fear which many Javanese harboured of walking into Kotabaru during the colonial days was transformed into a fear of the streets of Kotabaru itself. As a consequence of the loss of a sense of community, Kotabaru was deprived of its basic sense of boundary. Although still known as a fashionable, upper class district, the boundaries of Kotabaru became blurred. Few people today know where the boundaries are, as if Kotabaru has finally become fully incorporated within the city proper and has become a regular part of Yogyakarta.

\section{References}

Bosma, Ulbe and Remco Raben (2008). Being "Dutch" in the Indies: A history of creolisation and empire, 1500-1920. Singapore: Singapore University Press and Ohio: Ohio University Press.

Breton de Nijs, E. (1999). Faded portraits. Singapore: Periplus.

Colombijn, Freek (with the assistance of Martine Barwegen) (2010). Under construction: The politics of urban space and housing during the decolonization of Indonesia, 1930-1960. Leiden: KITLV Press. [Verhandelingen KITLV 246.]

Coté, Joost (2004). 'Colonial designs: Thomas Karsten and the planning of urban Indonesia', paper presented at the 15th Biennial Conference of the Asian Studies Association of Australia, Canberra, 29 June-2 July.

Dingemans, L.F. (1926). Gegevens omtrent Djokjakarta. Magelang: Maresch. 
Doorn, J.A.A. van (1994). De laatste eeuw van Indië: Ontwikkeling en ondergang van een koloniaal project. Amsterdam: Bakker.

Flieringa, Gellius (1930). De zorg voor de volkshuisvesting in de stadsgemeenten in Nederlandsch Oost Indië in het bijzonder in Semarang. Rotterdam: Rotterdamsche Boek- en Kunstdrukkerij Rotterdam. [PhD thesis, Technische Hoogeschool Delft.]

FWD (1935a). 'Trètès: Het buitenverblijf in de bergen', Woninggids voor Soerabaia $1: 4-6$.

FWD (1935b). 'Trètès als vacantie-oord', Woninggids voor Soerabaia 2:2-6.

Gorkom, W.J.van (1913). Ongezond Batavia, vroeger en nu. Batavia:Javasche Boekhandel \& Drukkerij.

Houben, Vincent J.H. (1994). Kraton and Kumpeni: Surakarta and Yogyakarta, 1830-1870. Leiden: KITLV Press. [Verhandelingen KITLV 164.]

Interlocale telefoongids (1938). Interlocale telefoongids voor Java, Madoera en Bali 46. [Batavia: Kolff.]

Locher-Scholten, Elsbeth (1997). 'Summer dresses and canned food: European women and Western lifestyles in the Indies, 1900-1942', in: Henk Schulte Nordholt (ed.), Outward appearances: Dressing state and society in Indonesia, pp. 151-180. Leiden: KITLV Press. [KITLV Proceedings 4.]

Locher-Scholten, Elsbeth (1998). 'So close and yet so far: The ambivalence of Dutch colonial rhetoric on Javanese servants in Indonesia, 1900-1942', in: Julia ClancySmith and Frances Gouda (eds), Domesticating the empire: Race, gender, and family life in French and Dutch colonialism, pp. 131-153. Charlottesville and London: University Press of Virginia.

Mrázek, Rudolf (2002). Engineers of happy land: Technology and nationalism in a colony. Princeton and Oxford: Princeton University Press.

Noorduyn, J. (1986). 'The etymology of the name of Yogyakarta', Archipel 31:87-96.

O'Connor, Richard A. (1983). A theory of indigenous Southeast Asian urbanism. Singapore: Institute of Southeast Asian Studies.

Schrieke, J.J. (1918). Ontstaan en groei der stads- en landgemeenten in NederlandschIndië. Amsterdam: De Bussy.

Tafuri, Manfredo and Francesco Dal Co (1986). Modern architecture. New York: Rizzoli. Volkstelling 1930 (1936). Volkstelling 1930/Census of 1930 in the Netherlands Indies, Vol. VIII Overzicht voor Nederlandsch-Indië. Batavia: Departement van Economische Zaken.

Wertheim, W.F. (1956). Indonesian society in transition: A study of social change. The Hague and Bandung: Van Hoeve. 